\section{THE SUSPECTED MURDER.}

Br a concurrence of circumstances that might well cause the most careless to panse and think, there has, apparently, just been brought to light the evidence of an atrocious murder. A carpet-bag, containing portions of the remains of a human being, was carried on to the north end of Waterloo-bridge, at half-past eleven o'clock last Friday night, to be got rid of by letting the bag and its contents quietly down into the water by means of a cord. This bridge and this hour were undoubtedly selected because a person carrying a heavy bag could then cross with out suspicion, since a train started from the terminus of the South Western Railway at a quarter to twelve o'clock. The bag was to be let down into the water, lest the splash occasioned by its being thrown over the parapet should be heard by watchmen listening for the sounds which too often give notice that "one more unfortunate, weary of breath," has sought refuge in a watery grave. From one of the recesses of the bridge the bag was carefully lowered until the strain was no longer felt, and then the cord by which it had been guided was also allowed to fall. But this very excess of caution defeated the iniquitous object. From one small portion only of the parapet of the recess could the weight have been so let down that it would alight on a shelving abutment of the bridge, a short distance above the level of the water. This one spot was that from which the bag was lowered; and the care with which the revolting burden was let down enabled it to rest on this shelving abutment, from which it would certainly have slid if allowed to fall rapidly or with a jerk.

The bag contained a portion of the bones of a man about five feet eight inches in height. The parts deficient were those by which identification could be established with greatest certainty, namely, the hands, feet, and head. In the bag were five lower dorsal vertebræ, separated by the division of the cartilages with a knife, and by cutting the processes with a saw. Considerable force had been employed, as a portion of the spinal cord had been dragged out of the canal of the upper dorsal vertebræ. The pelvic bones, larger than those of the male usually are, had been separated with laborious care. Attached to the pubis on one side was found a small portion of the corpus cavernosum, thus placing the sex beyond dispute. The left elbow and right knee had been bent at right angles when the body stiffened, and this was the condition in which it was fourd; the division of the femora having been effected by sawing through their shafts below the trochanters and also above the condyles. One upper extremity had been removed by sawing through the neck of the scapula. The sternum had been split by a vertical section. On all the bones remained fragments of muscle, which had been evidently roughly hacked away. The knife used was a blunt one, but the saw sharp.

We particularly mention these appearances, as they serve to refute a foolish rumour which was spread on the first discovery of the remains, that they had been deposited by some medical students for a "hoax." Such an absurd suspicion could only have originated in the densest ignorance. Students have no greater opportunities of obtaining possession of remains in the condition in which these were found than any other members of society, and we can only express our extreme disgust at the morbid obtuseness of the slanderer who dared to impute such a barbarous ontrage to intelligent and educated.men.
There was skin adherent to four parts of the remains-on the back of each wrist, on the tubercle of the right tibia, and over the left side of the sternum about its middle. In this latter situation there also remained a portion of the origin of the pectoralis, perforated by a stab, which was apparentIy inflicted during life, and penetrated between the third and fourth ribs. Now, the clothes had also been thrust into the carpet-bag, and in the left side of the shirt-front were marks of seven or eight stabs made by a thin clean blade, one of the holes precisely corresponding with the above-mentioned. incision. Had this small remaining fragment of flesh been removed, there would have been lost the most presumptive evi. dence of murder. Had the fragments not been by some means preserved, decomposition would have rendered it impossible to decide that this stab was inflicted previous to death. The clothes are perforated by many stabs, and have evidently been roughiy cut and torn from the stiffened body.

The parts of the body deficient, including the viscera and muscles, form a mass so difficult to appropriate, that the detection of the murderers may occur even whilst these observations are passing through the press. That more than one person was concerned seems probable. And there were found entangled amongst the remains long, fine, brown hairs, which lead to the suspicion that a woman, with her hair dishevelled, was present when the body was hewn to pieces.

We cannot enter into further details on this subject at the present time, for obvious reasons; but the points already indicated are of such professional interest that we need not apologize for commenting on them. It only remains that we should direct attention to the minute care and the great professional skill and intelligence with which the remains have been examined by the police surgeon, Mr. R. B. Parnter, of Brydges-street.

(Letter from Mr. Richard Budd Painter, Surgeon to the F Division of the Metropolitax Police Force.)

\section{To the Editor of The LanceT.}

SIR,-As I find there is still an opinion held by a few medical gentlemen, as well as by some of the public, that the bones recently found at Waterloo-bridge are not those of $a$ murdered man, but the remains of a dissection, I think it may be well to send you a short account of what I have observed hitherto in the matter, especially as I am the only medical practitioner that has yet reported on the case. I therefore propose, on the present occasion, to give a short anatomical description of the case, and will possibly, at a future period, give a more detailed account.

On being shown the bones at the Police-station, I pro. ceeded to fit them together, and soon ascertained that they all belonged to one person--an adult man of an average, or perhaps above the general size. The head, the whole of the viscera, all the cervical and seven of the dorsal vertebræ, were wanting, also the left clavicle, portions of the ribs, acromion process of the right scapula, both hands, both patellæ, lower third of the left fibula, and both feet and tarsi. Of the bones present, five dorsal and two lumbar were in one piece, the ribs being sawn from the former. The upper and lower portion of this piece of the backbone was separated from its adjoining bones by cutting the intervertebral substance with a knife, and the articular and transverse processes with a saw. The lower lumbars were cut in half through their bodies and attached to the pelvis. There were five portions of the thorax, three of them belonging to the right side, and forming, when put together, eleven ribs nearly complete; the two other portions were from the left side, one of which consisted of probably the second, 
third, and fourth ribs, with part of the sternum. Between the third and fourth ribs, near the sternum, was a cleanly $\cdot$ cut stab, having its long axis upwards and downwards, and exactly corresponding with the direction and position of the cuts in the coat and under-waistcoat. Around this wound, for a distance of two inches, blood was infiltrated into the tissues both external to the thorax as well as beneath the pleura. The next ribs below, probably two or three, were missing, the other piece of the left side above-mentioned being most likely parts of the seventh, eighth, and ninth. Thus the ribs immediately beneath the parts where the greater number of stabs in the clothes appear are missing. But the characters of the cut above-mentioned are quite conclusive as to the wound being inflicted during life. The thorax liad not been opened in the invariable (as I believe) manner of anatomists-viz., by cutting the costal cartilages, but the sternum was sawn down the middle vertically. The right clavicle was left hanging to the upper rib, and had a square inch of dark skin on it. The right scapula was detached, and had lost its acromion by the saw, and was ronghly disarticulated from the humerus. The right radius and ulna were in one piece, but separated by rough disarticulation from the humerus and hand. The left scapula was also separate, but sawn from the humerus, to which the neck remained attached. At the elbow-joint the heads of the left radius and ulna, partly sawn and partly broken off by great force, were also attached to the humerus. The remaining portions of radius and ulna were together, and pronated. On the back of each wrist was a large patch of dark skin, with numerous long, black, or darkish hairs.

The pelvis was divided with a knife (I believe) at the symphysis pubis, and with a saw down the centre of the sacrum. It was of large dimensions, the internal measurements being at the brim fire inches lateral, and four inches and a quarter antero-posterior. Attached to one of the rami was a distinct portion of the corpus cavernosum. The heads of both femora were articulated, but sawn from their shafts below the trochanters. The right stump had muscle around it, and was firmly fixed, pointing almost at right angles to the body of decessed. The capsular ligament of the left hip-joint was cut open, and an endeavour bad been made to wrench out the head of the femur, but it was held by the ligamentum teres. The shafts of the femora were again cut just above the condyles, the right lower portion still remaiuing attached to the tibia. The left was separated and detached by rough cutting. The right tibia was cut at the junction of its lower third. The right fibula was similarly divided and detached. The left tibia and fibula were similarly sawn. The lower portions of the right tibia and fibula and the left tibia formed separate fragments, and were disarticulated from the missing tarsi. The right knee was strongly flexed, and had a large piece of skin with hair, as on the wrists, firmly adherent to the head of the tibia.

All the bones had portions of museles, nerves, arteries (uninjected), \&c., adhering, cut about in a rough, "haggled" manner, and had not been dissected. The colour of the parts was reddish-brown externally, redder if cut into. No decomposition had taken place, excepting in the left acetabulum, where there were blue discolorations, and a very strong smell of putrefaction. No portions of skin were present but those named. From the condition of the tendons, arteries, cuticle, c., I should not wonder if the parts had been boiled.

It is evident that when cadaverous rigidity set in, the right thigh and leg were strongly drawn upwards and outwards, the latter partly flexed on the former. The left humerus must have been abducted from the side, and the forearm half flexed and pronated at the same time.

Some dark hairs were adherent to the remains, and also a few long ones of a lighter colour. Some saline gritty particles were found on the muscles, \&c. These will probably be analyzed.

I think I have said enough in this hurried note to show that a foul murder has been committed. I have not time to add more, or speak of the clothes, and my chief object in writing this at all, is to endeavour to free my medical brethren from the horrible imputation that they dispose of their subjects, used for study, in such a manner as this.

I am, Sir, your obedient servant, Rrchard Budd Painter, M.R.C.S.

Brydges-street, Covent-garden, Oct. 15th, 1857.

\section{THE NATIONAL ASSOCIATION FOR THE PRO. MOTION OF SOCTAL SCIENCE.} Soctal Economy.

Ar the first meeting of the Association, held at Birmingham on Monday last,

SrR B. BRoDre, who has undertaken the presidency of the Fifth Department in the unavoidable absence of Lord Lyttelton, owing to a domestic afliction, was introduced to the meeting. In briefly reviewing the reforms which it was neces. sary to undertake in order to the advancement of the principles of social economy, he urged the necessity of looking below the surface, and taking a far more comprehensive view of these matters than persons were ustually apt to do. For example, in considering the social evils to which the poorer portions of the public were more particularly liable, it would not be enongh merely to endeavour to prevent drunkenness, but to take into view the whole question of the effect of drinking habits gene. rally; they should then go to the educational section, and ask for information as to the means provided for the intellectual instruction and amusement of the poor, and thence they should proceed to the sanitary section, and ascertain what measures were being adopted to secure the healthy and comfortable con. dition of the home of the working man. (Hear, hear.) The subjects which came within the province of the social economy department were of a miscellaneous and almost a heterogeneons description; but having regard to that economy of time which was essential, he left these various subjects to be discussed more in detail in the section over which he was about to pre. side. Touching upon the question of public charities, Sir Benjamin observed that many of these institutions were open to the serious charge of paralysing that spirit of independence and self-reliance which was more valuable to a man than any amount of charity that could be given him. As an instance of this, he cited the case of a London parish, to which, within his own knowledge, persons removed for the express reason that large sums of money were given away there; while he knew that in other cases the existence of almshouses attracted to the parish numbers of the idle, dissolute, and worthless. He remarked also upon the large amount of money which was expended by many public charities in " establishment charges" before any of it was distributed to deserving objects; and in other cases upon the cost which poor persons had to incur before they could avail themselves of the benefits which the charities were calculated to confer. In conclusion, Sir Benjamin ex. pressed a hope that the subject of our great pnblic charities would ere long engage the attention of those who were competent to deal with them, and to propose a remedy for the existing evils.

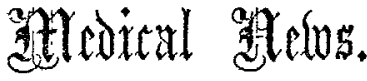

Royal College of Surgeons.-The following gentlemen, having undergone the necessary examinations for the Diploma, were admitted members of the College at the meeting of the Court of Examiners on the 9th inst.:-

Applin, Augustin Oliver, Army.

Braden, John Grorge, Commercial-road East.

Erzis, James, St. Thomas's Hospital.

GrabHam, George Wallington, St. Thomas's Hospital, Lowr, JoHn, Lynn Regis, Norfolk.

Mansed, Thomas, Pembroke.

Molyneaux, James, Manchester.

Tench, Edward Beavan, Hereford.

At the same meeting of the Court, Messry. JoHn Mortwock Tronson, of H.M.S. Wellington, and WILLTaM JaRreTt leawrs, of Haslar Hospital, Portsmouth, passed their examinations as Naval Surgeons. These gentlemen had previously teen ad. mitted members of the College, their diplomas bearing date respectively August 6th, 1852, and May 15th, 1854. 